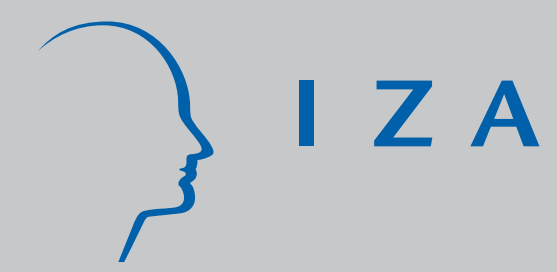

IZADP No. 1957

Product Markets and Paychecks: Deregulation's Effect on the Compensation Structure in Banking

Abigail Wozniak

J anuary 2006 


\title{
Product Markets and Paychecks: Deregulation's Effect on the Compensation Structure in Banking
}

\author{
Abigail Wozniak \\ University of Notre Dame \\ and IZA Bonn
}

Discussion Paper No. 1957

January 2006

IZA

P.O. Box 7240

53072 Bonn

Germany

Phone: +49-228-3894-0

Fax: +49-228-3894-180

Email: iza@iza.org

Any opinions expressed here are those of the author(s) and not those of the institute. Research disseminated by IZA may include views on policy, but the institute itself takes no institutional policy positions.

The Institute for the Study of Labor (IZA) in Bonn is a local and virtual international research center and a place of communication between science, politics and business. IZA is an independent nonprofit company supported by Deutsche Post World Net. The center is associated with the University of Bonn and offers a stimulating research environment through its research networks, research support, and visitors and doctoral programs. IZA engages in (i) original and internationally competitive research in all fields of labor economics, (ii) development of policy concepts, and (iii) dissemination of research results and concepts to the interested public.

IZA Discussion Papers often represent preliminary work and are circulated to encourage discussion. Citation of such a paper should account for its provisional character. A revised version may be available directly from the author. 


\section{ABSTRACT \\ Product Markets and Paychecks: Deregulation's Effect on the Compensation Structure in Banking ${ }^{*}$}

This paper asks how deregulation intended to promote competition in the commercial banking industry affected the compensation structure for banking employees. Using establishment-based data from the Employment Cost Index Survey of the U.S. Bureau of Labor Statistics, I obtain measures of the level and distribution of wage and benefits compensation within industries. I then compare changes in compensation in the banking industry to changes in unaffected industries across states and over time to identify the effects of deregulation. Banking deregulation had no effect on compensation levels or inequality in the industry as a whole, but this masks conflicting changes within the compensation structure. Manager wages fell while non-manager wages held steady, leading to a large decline in between-occupation compensation inequality. In contrast, between-establishment inequality increased dramatically. Deregulation also led to increases in inequality among managers despite their falling wages and to significant shifts in the types of non-wage benefits banking employees received.

JEL Classification: J31, L11

Keywords: total compensation, compensation inequality, product market competition, commercial banking

Corresponding author:

Abigail Wozniak

Department of Economics and Econometrics

Flanner 441

University of Notre Dame

Notre Dame, Indiana 46556

USA

E-mail: a_wozniak@nd.edu

\footnotetext{
* I thank the National Science Foundation, Harvard University and the Social Sciences Research Council for support. I thank the U.S. Bureau of Labor Statistics and Brooks Pierce, John Ruser, Carl Barsky, and William Wiatrowski in particular for the gracious provision of data, research space and expertise. The comments of many improved this paper. In particular I thank Lawrence Katz, David Cutler, Claudia Goldin, Caroline Hoxby, Lawrence Kahn, two anonymous referees, and participants in the Harvard Economics Labor and Public Economics Workshop. Alessandra Bosco and Magali Fassiotto provided excellent assistance. This research was conducted with restricted access to the Bureau of Labor Statistics (BLS) data on-site at BLS. The views expressed here are those of the author and do not necessarily reflect those of BLS. I will gladly share all programs and log files upon request. Due to the confidential nature of the Bureau of Labor Statistics data, interested researchers must apply to BLS for researcher access to the data.
} 
Goods markets and labor markets are necessarily linked. Before selling their products in goods markets, firms first purchase their workers' productive capacities in the labor market. As the product market changes accompanying deregulation and globalization proceed apace, questions about how conditions in goods markets relate to labor market outcomes take on new importance. This paper examines the effects of increased competitiveness in an industry's product market on the compensation structure for the affected industry's employees. To identify effects of increased competition with changes in an industry's compensation structure, I take advantage of state-level changes to laws regulating entry into the commercial banking industry. The repeal of these laws lowered barriers to entry and reduced restrictions on scale, leading to a more competitive environment for a state's banking firms.

The effects of increased competition on labor market outcomes in an industry are more difficult to predict than its effect on goods prices. Removing barriers to entry in an industry leads to lower prices for the industry's goods through a simple mechanism. When barriers are removed, firms that can produce more cheaply enter the industry and compete away any profits or inefficiencies arising from the defunct entry restrictions. In contrast, competition's effects on labor market outcomes will generally depend on conditions of wage setting under the regulatory régime. The effect of increased goods market competition on the compensation structure for workers in the deregulated industry is less straightforward but may nevertheless be considerable. A few brief examples will make this dependency clear.

First consider an industry where owners are powerful (or well-informed) relative to workers. In this case, the level of compensation in the industry will change little following deregulation. This is because powerful owners purchased their workers' labor in a competitive labor market and would have succeeded in retaining any regulatory rents for themselves. By contrast, if workers have bargaining power relative to owners, they may be able to retain some regulatory rents for themselves 
in the form of above-market compensation. Compensation in this case will fall as competition erodes the rents of the regulatory régime. Dispersion of compensation within an industry may also change following deregulation if some groups of workers are more successful than others at appropriating rents. Moreover, erosion of rents is not the only mechanism through which competition may alter the compensation structure in an industry. Competition may drive firms to seek out niche markets by producing exclusively higher or lower quality goods, and producers of specialized goods in turn may demand specialized labor inputs of high or low quality, leading to greater dispersion in pay across establishments.

These examples show that the effects of increased competition on employee compensation will differ from industry to industry. They also highlight the potential for product market liberalization to operate on worker compensation through multiple channels. Deregulation may also lead to compensation changes through the easing of other restrictions, not just barriers to entry. Despite the numerous changes in worker compensation one might expect liberalization to effect, few studies have undertaken an exhaustive review of compensation structure changes associated with industry deregulation. Those that have focus on unionized, capital-intensive industries, rather than growing service-sector industries like commercial banking.

This paper uses a restricted data set to go beyond earlier studies of deregulation's effect on banking industry wages. The data come from a survey of establishments conducted by the U.S. Bureau of Labor Statistics to construct their quarterly Employment Cost Index (ECI) and are used by special permission. The ECI data have two distinct advantages. First, the data include establishment identifiers, which allow me to examine effects of deregulation on dimensions of the compensation structure that are not generally observable in the standard individual-level data sets. Second, I am able to use the ECI's information on benefits expenditures to construct measures of total compensation, which allow me to compare deregulation's effects on wages to its effects on 
compensation more generally. Since the ECI data contain annual observations on a representative set of establishments, I can use state-level changes in banking laws to identify deregulation's effects on the banking compensation structure at the state-year-industry level.

In addition, the ECI data provide an alternative to the limited number of nationally representative data on labor market outcomes. Thus the ECI enables me to compare results obtained using an important restricted-access data set with those obtained from a widely available individual-level data set. I supplement findings from the ECI, which contains limited background information about workers, with analysis using one such individual-level data set, the Current Population Survey (CPS). Results from the ECI provide a unique set of facts about the various ways in which deregulation altered the compensation structure for banking employees. The CPS evidence enables me to add detail to my interpretation of the ECI results. By combining results from these data sources, this paper documents a number of changes throughout the banking compensation structure following deregulation and provides a more complete picture of deregulation's effects on employee compensation than has previously been available.

\section{Commercial Banking under Regulation and Deregulation}

In 1920, $98 \%$ of banking firms in the U.S. were single office banks, or unit banks. States used a chartering process to control which banks operated within their borders. The required charter typically allowed a bank to serve a limited geographic area from one office. As a growing middle class began to demand greater access to savings instruments and deposit institutions, tension developed between small and large banks as each side sought to protect and expand its share of the commercial banking market. ${ }^{1}$ The debate culminated in federal legislation known as the McFadden-

\footnotetext{
${ }^{1}$ For a longer history of commercial banking in the United States, see White (1983) and P. Rose. For details on the origins of the state charter system of banking regulation, see Sylla et al. (1987).
} 
Pepper Act in 1927. McFadden-Pepper was a victory for small banks. It enshrined unit banking as the legal default and banned both intrastate and interstate branching unless a state passed legislation expressly permitting branching. States retained their monopoly over bank charters within their borders. The influence of protected banks combined with public concern about "excessive" numbers of banks that followed the Great Depression meant that state chartering institutions continued to protect small, non-competitive banks for much of the 1940s, 1950s and 1960s. ${ }^{2}$

The unit-bank or near unit-bank (extremely limited branching) market structure remained the norm in commercial banking until the late 1960s, when states began passing laws permitting various forms of bank branching. The legislative battles leading to state-level deregulation during this period rehashed the fight that led to passage of McFadden-Pepper, as more successful banks continued to press for the right to expand into other markets. ${ }^{3}$ In the intervening decades, events had also occurred to change the calculus in the bank branching debate. The savings and loan failures of the 1980s and deep recessions in some states led many to question the wisdom of a strictly atomized system of credit (Kroszner and Strahan, 1999). The advent of ATMs also helped to spur a new round of debate as regulators argued over whether a freestanding ATM constituted a branch of its parent bank.

In most states, the watershed event in commercial banking deregulation was legalization of branching via mergers and acquisitions. ${ }^{4}$ M\&A branching allowed an existing bank to create a

\footnotetext{
2 The facts in this paragraph were drawn largely from Chapter 3 of White (1983) and Chapter 7 of Rose (1987). For details of the McFadden-Pepper legislation, see the White chapter.

${ }^{3}$ See Kroszner and Strahan (1999) and Kane (1996) for empirical studies of the political economy of banking deregulation. Economides et al. (1995) develops and tests a political economy theory of commercial banking deregulation.

${ }^{4}$ Laws permitting multibank holding companies were the first deregulatory legislation to be passed. This first wave of laws allowed holding companies to control ownership stakes in multiple banks, but the consolidation of operations
} 
branch by merging with or acquiring another bank and enabled banks to consolidate operations across different physical locations for the first time. Moreover, successful banking firms could finally compete directly in geographic markets previously controlled exclusively by other banking firms.

Changes to the product market environment in commercial banking following deregulation potentially affected the industry compensation structure through two broad channels. First, existing banks may have changed their behavior with the onset of deregulation. For example, if noncompetitive rents disappeared following deregulation, banks may have lowered wages for employees who had previously been successful at capturing part of these rents. Alternatively, existing banks may have decided to hire a different skill mix of workers to meet the pressures of a more competitive environment. ${ }^{5}$ The second channel is less direct. Deregulation enabled substantial changes in the composition of the industry, which may have led independently to changes in the banking compensation structure. In particular, deregulation did away with many of the barriers to entry in the banking industry, allowing a large number of new and perhaps more specialized firms to enter. Deregulation also allowed banks to achieve a much larger scale of operations. This last change represents something of a hybrid of the two channels. It led to a shift in the distribution of firm sizes throughout the industry, changing this dimension of industry composition significantly, but the shift was achieved at least in part through growth of existing firms. ${ }^{6}$

across these banks was severely curtailed (Watts, 1994). See Berger, Kashyap, and Scalise (1995) for a thorough overview of regulatory changes affecting the banking industry after 1979.

${ }^{5}$ For a theory of skill segregation across firms, see Kremer and Maskin (1996).

${ }^{6}$ See Brown and Medoff (1989) for a discussion of the robustness of firm size wage premiums. For evidence on differences in lending practices across small and large banks, see Berger et al. (2005). 
Previous authors who have explored the relationship of product market competition to wages have typically been forced by data considerations to study its effect on industry-wide wage levels. $^{7}$ In a relevant study, Black and Strahan (2001) show that male banking employees were adept at rent-taking, and they attribute a large share of the narrowing gender wage differential in banking to deregulation. ${ }^{8}$ In two of the few firm level studies of competition's effects on banks, Jayaratne and Strahan (1998) and Flannery (1984) find evidence that more regulated banks earn excessive profits. ${ }^{9}$ As mentioned above, deregulation may lead firms to change compensation for reasons other than rent erosion. Guadalupe (2003) examines a range of industries and finds that increasing within-occupation inequality accompanies deregulation. She argues that the pressures of increased product market competition raise the cost of worker mistakes, leading firms to reward competence and performance more highly and increasing inequality among workers in a given occupation. Hubbard and Palia (1995) find evidence that this phenomenon occurs in banking. They report that CEOs in more competitive banking markets receive higher average pay that is more sensitive to performance than their counterparts working in less competitive markets.

The shifts in industry composition along size and product diversity dimensions have been explored by finance economists, but little is known about the labor market impacts of these changes. Expansion of efficient firms following deregulation led to a well-known increase in measures of industry concentration at the national level. At the local level, however, the industry's tendency toward increased concentration was far from uniform. Bergstresser (2001) shows that half the

\footnotetext{
${ }^{7}$ Examples include Card (1996) N. Rose (1987), and Black and Strahan (2001), who also studied wage changes in banking following deregulation. See Winston (1993) for an overview of these and others. See OECD (2002) for a crosscountry study of the relationship between product market regulations and labor market outcomes in European countries. ${ }^{8}$ Black and Brainerd (2004) also find evidence of gender-biased rent allocation across a number of industries. ${ }^{9}$ Jayaratne and Strahan (1996) also find that deregulation improved efficiency in the banking industry.
} 
MSA's affected by branching reform experienced declining levels of concentration among their commercial banking firms. ${ }^{10}$ Rhoades (2000) notes that the number of banking firms in the United States fell by approximately 40\% between 1984 and 1998, but the number of bank establishments (offices) continued to grow at a stable rate over the same period. Indeed, the growth in the number of bank branches appears to have prevented any real decline in employment for bank tellers, who were largely being replaced by ATMs during this period. The efficiency effects of this increase in scale among a subset of firms has received comparatively little study. One reason may be that scale effects in commercial banking are not large, as some authors have suggested (Nakamura, 1993), and thus repealing restrictions on scale had little effect on the industry.

\section{Empirical Strategy and the Employment Cost Index Data}

The empirical approach in this paper is straightforward. I use the timing of state-level deregulation legislation to identify exogenous changes to the product market environment for a state's commercial banks. ${ }^{11}$ Following other authors, I use the year that a state passed legislation permitting branching via M\&A to mark the beginning of the deregulated period. Table 1 lists the 50 states in the order in which they adopted key legislation deregulating their commercial banking

\footnotetext{
${ }^{10}$ Conflicting trends in industry concentration at the local level were the results of a more competitive market for banking services. Efficient firms expanded relative to less efficient firms, increasing concentration in their local markets. At the same time, new firms entered to compete against incumbents. In areas where incumbent banking firms were particularly inefficient, the market was divided among newcomers and a stagnating incumbent, leading to decreased concentration.

11 Once a state passed laws allowing M\&A branching, laws permitting branching via other channels generally followed soon after. However, the short intervals between M\&A branching legislation and subsequent deregulatory legislation make identification of separate effects for each level of deregulation difficult.
} 
markets. Due to concerns about the ECI's representativeness prior to 1987, the treatment group consists only of states that deregulated after 1987.

I regress measures of compensation and the compensation structure on an indicator for a state banking industry's deregulation status to arrive at reduced-form estimates of deregulation's effect on the compensation measures. Because the relevant legislative changes targeted a single industry, this identification strategy produces triple difference estimates of deregulation's effect on the banking compensation structure. Measures of the banking compensation structure are compared with those in other industries in the same state and year. The differences are then adjusted for state, year and industry effects. ${ }^{12}$ This paper's true innovation comes not from its empirical methodology but from the setting in which these methods are applied. By using a data set in which it is possible to match wage and benefits information across employment establishments, I am able to construct a number of compensation and compensation structure measures that cannot be observed with more traditional microdata.

The data are from the U.S. Bureau of Labor Statistics Employment Cost Index (ECI) microdata, collected by BLS to track wages, benefits coverage, and benefits costs. ${ }^{13}$ The ECI data are collected using a survey of establishments randomly drawn from within strata defined by establishment size, industry and location. In keeping with its purpose as an index of employer costs, the ECI data contains no individual worker-level or demographic information. Instead, the

\footnotetext{
${ }^{12}$ Despite some correlation of banking deregulation with state macroeconomic trends, I maintain, as other authors have done, that the exact timing of the legislation was uncertain and that no evidence exists to suggest that workers anticipated the legislation's effects (Black and Strahan, 2001; Jayaratne and Strahan, 1998). Moreover, the inclusion of several levels of industry, state and time controls should alleviate concerns that my results stem from slow-moving trends in the wage structure for affected employees.

${ }^{13}$ For detailed discussions of the ECI data see the Data Appendix to this paper, Pierce (2001), or U.S. Department of Labor (1997).
} 
observational unit in the ECI is the "job." One should think of a job as an occupation-union statusfull-time status cell. The establishment provides data averaged over all employees in sampled jobs. Data for between two and eight jobs are collected from each establishment, depending on the establishment's size. Banking establishments typically provide data on four to six jobs.

Analysis in this paper focuses on changes in wages and benefits coverage among banking employees following deregulation. Due to the nature of the ECI data, wages are constructed at the job level and equal a job's average wage within the establishment. Benefits coverage is also defined at the job level. Establishments report expenditures on 15 different benefit categories for each sampled job. A job is "covered" if the establishment reports positive expenditures in a given benefits category. Following Pierce (2001), I also construct a total hourly compensation figure at the job level by summing the wage and hourly benefits expenditures reported for each job. ${ }^{14}$

Means for several ECI variables appear in Table 2. Throughout the paper, data are weighted using BLS-constructed weights to ensure representativeness of the original stratified sample. ${ }^{15}$ The final set of columns gives means for the ECI as a whole, and the preceding columns give means for the commercial banking industry alone. ${ }^{16}$ Several comparisons within Table 2 are relevant to questions about the generalizability of the results in this study. Wage levels in commercial banking

\footnotetext{
${ }^{14}$ See Pierce (2001) for a discussion of how employer benefits costs relate to employee evaluation of benefits.

15 Weights are adjusted to correct for attrition and make the rotating panel representative of the national economy each year. For details on this procedure, see the Data Appendix. Note that the number of state-year-industry cells is considerably less than what might be expected given 50 states, 14 years of data and two digit industries. The discrepancy stems in part from the fact that government and agricultural jobs are excluded. Moreover, the sampling procedure of the ECI does not necessarily sample from all industries in all states. It is intended to be representative of national employment in an industry, not state-level employment. 16 Throughout this paper, banking industry observations include only commercial banks, savings institutions, and credit unions.
} 
are close to the economy average over the period. ${ }^{17}$ The entire series of mean wages is shown in Figure 1. Wages in banking declined slightly over the period while wages in the economy as a whole were flat. In results not shown here, wage variance in banking was lower than in the economy as a whole during the period covered by the data. In terms of the share of non-managerial jobs and the share of union jobs, banking looks quite different from the ECI average, but it is similar to the service jobs in FIRE (finance, insurance, and real estate) on these measures. Banking is not unionized and seems to have a slightly higher fraction of managerial jobs than the economy as a whole. The fraction of full-time jobs appears high relative to similar figures from other sources, such as the CPS, but this is consistent with other estimates from the ECI. Banking employees also tend to receive two key forms of non-wage compensation, severance and bonus packages, more often than the average ECI employee.

A final trend to notice in Table 2 is the sharp decline in the size of the median banking establishment. The sampling procedure for the ECI is biased towards larger establishments, thus the levels may appear high relative to other sources, and some of the decline in median size is probably due to an increase in the sample size in 2000, which would favor smaller establishments. Nevertheless, the size of the median banking establishment falls by almost 300 employees, from 468 in 1987 to 179 in 2001 . This is likely due in part to the effects of deregulation over the period, which allowed banks to create smaller partial-service branches. ${ }^{18}$

The major shortcoming of the ECI data is its lack of demographic information on the workers included in its sampled jobs. I attempt to compensate for this shortcoming by using the

\footnotetext{
${ }^{17}$ All wages are in constant dollars. The 1982-1984 CPI average is the deflator.

${ }^{18}$ Establishment size numbers are unweighted. The number of unique banking establishments increases over the life of the sample, from 112 in 1987 to 265 in 2001 . Due to the ECI's sampling procedure, these contain many of the largest banks in the U.S., which accounts for the high average establishment size.
} 
March extracts from the Current Population Survey to replicate and extend the ECI analysis in instances where a comparison with estimates from a more representative sample with known background characteristics would be useful. The CPS sample spans 1977 to 1999 and includes all workers who were employed during the year prior to the survey.

\section{Results: Deregulation's Effects on the Banking Compensation Structure}

In a descriptive study like this one, the order of the empirical analysis is somewhat arbitrary. I first examine the effects of banking deregulation on broad measures of compensation inequality, since this is an area in which the ECI data have much to contribute. I then turn to the question of how the changes in inequality that I identify came about. It is in this context that I examine deregulation's effect on wage levels in banking. The final results in this section exploit the ECI's second strength and consider deregulation's effects on the types of non-wage benefits banking employees receive.

\section{A. Broad Changes in Compensation Inequality}

I decompose variance in the banking compensation structure into between establishment, between occupation, and residual components. Following Groshen (1991), I use dummy variable regressions to produce upper bound and lower bound measures of the contributions of establishment and occupation to compensation variance. ${ }^{19}$ Both methods produce establishment and occupation variance measures for state-year-industry cells as well as measures of residual variance. The lower bound measures also separately estimate variance explained by the interaction of establishment and occupation. The upper bound measures assign this variance, due to covariance

\footnotetext{
${ }^{19}$ For more details on this procedure, see Groshen (1991).
} 
between establishment and occupation, to its measures of both establishment and occupation variance.

Table 3 provides summary statistics for the various upper and lower bound measures of the wage and total compensation variance components. The relative contributions of establishment and occupation differ little across the two types of compensation decomposed. Also, establishment's and occupation's contributions are quite similar across the to decomposition methods. This is due to the fairly small contribution of the establishment-occupation interaction to overall variance in both wages and total compensation. In all four decompositions, a large share of the variance remains unexplained.

The results of interest are from secondary regressions like the following:

$$
y_{\mathrm{kst}}=\beta_{0}+\beta_{1} \text { banking }{ }^{*} \text { dereg }+\beta_{2} \text { dereg }+\theta_{\mathrm{k}}+\theta_{\mathrm{s}}+\theta_{\mathrm{t}}+\varepsilon_{\mathrm{kst}}
$$

where $y$ is one of the measures of compensation variance, $k$ indexes two-digit industries, $s$ indexes state, and $t$ indexes year. $\theta_{\mathrm{k}}, \theta_{\mathrm{s}}$, and $\theta_{\mathrm{t}}$ are dummy variables for industry, state, and year. The dereg variable is equal to one in years following a state's deregulation of its banking industry.

The banking-deregulation coefficient from the second stage regressions should be interpreted as a triple difference. It is deregulation's effect on the banking industry wage structure relative to non-affected industries after controlling for state and year effects. A state's decision to deregulate its banking industry may depend on prevailing economic conditions in the state. ${ }^{20}$ To account for this, I verified that all results are robust to the inclusion of state-year fixed effects, which control for any non-linear, state-level compensation structure trends over the period.

The tables will show results using all ECI industries as the comparison group of nonaffected industries. Unreported results using alternative comparison industries, such as FIRE, were

\footnotetext{
${ }^{20}$ Jayaratne and Strahan (1998) find evidence that states tend to deregulate their banking sectors during state-level downturns.
} 
not substantively different. Also note that the decompositions only included two occupation groups, managers and non-managers, so between-occupation results should be interpreted as reflecting changes between these two groups. ${ }^{21}$

Results from estimation of equation (1) are summarized in Tables 4 and 5, which present estimates using the lower and upper bound decomposition measures, respectively. Each column in the tables represents a separate regression of the dependent variable in the column heading on dummy variables for deregulation, state, year and industry, and the interaction of banking and deregulation. The first column in the two tables is the same: it estimates the effect of deregulation on total variance in banking industry compensation. In addition, each table shows results using measures from decomposition of total compensation (wages plus benefits) and from decomposition of wages alone.

The first result to notice in Tables 4 and 5 supports a null hypothesis: deregulation had no effect on wage inequality among banking industry employees and little effect on total compensation inequality. However, this conceals two pronounced but conflicting trends within the compensation structure. First, deregulation led to a significant reduction in between-occupation inequality. The estimated impacts of deregulation on this measure in the second columns of the two tables are large and significant. The coefficient from the decomposition of wages in Table 4 represents a decline of $25 \%$ from the mean of pre-deregulation between-occupation variance. The upper bound estimate from Table 5 is somewhat smaller but still implies a reduction of between-occupation variance of $19 \%$ from the mean. Estimates using the decomposition of total compensation are very similar.

\footnotetext{
${ }^{21}$ I considered only two occupation groups because the ECI only categorizes occupations at the one digit level. At this level of classification, one managerial category and one non-managerial category comprised virtually all of the jobs, so I grouped the few remaining jobs into either the manager or non-manager categories.
} 
A second, opposing effect of deregulation on the compensation structure is apparent: deregulation increased between-establishment compensation variance. This, combined with the changes in between-occupation variance, resulted in stable total variance following deregulation. The effect of deregulation on between-establishment wage variance in banking is 0.0158 using the lower bound method and 0.0236 using the upper bound method; both are significant. The estimates are similar in the decompositions of total compensation but not quite significant, with p-values of 0.102 and 0.101 using the lower and upper bound method, respectively. These results imply large increases of $30-50 \%$ from the mean in the level of between-establishment inequality in the banking industry. ${ }^{22}$

\section{B. Between-Occupation Changes}

The broad compensation structure changes described in the previous section could have been accomplished in any of several ways. To understand more about how these changes were achieved, I use more detailed wage equations to examine falling between-occupation inequality following deregulation. I estimate the following version of a wage equation for the ECI sample with unit of observation job $j$ in establishment $k$ at time $t$ :

\footnotetext{
${ }^{22}$ Note that in this setting, the dependent variables are measures of dispersion in predicted, rather than actual, values. In cases where the sample sizes used to form predicted values are very small, as is the case with the establishment dummies, variance in the predicted values may be large due to sampling error. This problem is not likely to be more severe for banks than for other industries, so the triple difference will largely difference out this noise. (I am grateful to a referee for pointing this out.) However, I would add that some of the increase in between-establishment variance may be due to the decline in banking establishment size following deregulation, which would have increased noise in the predicted values relative to their pre-deregulation values.
} 


$$
\begin{aligned}
& \ln y_{j k t}=\beta_{0}+\beta_{1} \text { banking dummy }_{k}+\beta_{2} \text { deregulation }_{k t}+\beta_{3} \text { manager }_{j k}+\beta_{4} \text { banking }_{k}^{*} \text { deregulation }_{k t}+ \\
& \beta_{5} \text { banking }_{k}^{*} \text { manager }_{j k}+\beta_{6} \text { deregulation }_{k t}^{*} \text { manager }_{j k}+\beta_{7} \text { banking }_{k}^{*} \text { deregulation }_{k t}^{*} \text { manager }_{j k}+ \\
& \beta_{8} \text { union }_{j}+\beta_{9} \text { full-time }_{j}+\beta_{10} \text { non-manager }_{j k}{ }^{*} \text { union }_{j}+\beta_{11} \text { non-manager }_{j k}^{*} \text { full-time }_{j}+\beta_{12} \text { additional controls }+\varepsilon_{\mathrm{jkt}}
\end{aligned}
$$

where $\mathrm{y}$ is either wages or total compensation. The additional controls consist of state-year fixed effects, banking-specific state effects, and banking-specific year effects. Results are presented in Table 6.

I first constrain the effect of deregulation in Equation (2) to be the same for managers and non-managers. Results in columns [1] and [4] of Table 5 show that deregulation had no effect on the level of wages or compensation for the average banking employee. ${ }^{23}$ I then allow the effect of deregulation on banking employee compensation to differ for managers and non-managers. Results in columns [2]-[3] and [5]-[6] indicate that reduced between-occupation inequality following deregulation was accomplished through reductions in bank manager wages relative to non-manager wages. The level effect of deregulation on bank manager wages was large and negative, implying a decline of approximately $17 \%$ after deregulation and declines in total compensation of $20 \%$. The triple interaction indicates that non-manager banking employees, however, were totally insulated from these effects. F-tests at the bottom of the table show that narrowing in wages led to significant net gains for non-managers, but the narrowing in total compensation only held non-manager compensation steady. ${ }^{24}$ In general, estimates are similar across specifications using the two different

\footnotetext{
${ }^{23}$ In contrast, Black and Strahan (2001) find declining average wages in banking using CPS data.

${ }^{24}$ Interestingly, Fortin and Lemieux (1997) find that deregulation explains little of the rising wage inequality between more and less educated workers in the 1980s. One reason may be that deregulation-especially in non-unionized industries — can reduce wage differentials between more- and less-educated workers. This was the case in banking.
} 
dependent variables and including interactions of the non-manager indicator with the union and fulltime dummies.

The establishment identifiers in my data allow me to test the hypothesis that this betweenoccupation narrowing is an artifact of changing establishment composition in the industry. Recall that an establishment remains in the ECI data for approximately five years. I construct the ratio of log manager compensation to log non-manager compensation within establishments and regressed this ratio on state, year, and establishment dummies, and the banking-deregulation interaction. The results from this regression in Table 7 show that deregulation led to decreased wage inequality between managers and non-managers within the same establishment, although the effect is not significant. Given the extremely small number of establishments that are actually used to identify this estimate, the fact that the coefficient has the expected negative sign provides weak but suggestive evidence that deregulation lowered between-occupation inequality within existing banking establishments.

Without more detailed information about worker characteristics, it is difficult to know what is driving this relative decline. In fact, a decline in manager wages relative to non--editor wages is precisely the opposite of the between-occupation changes documented in Black and Strahan (2001), who found that non--managers lost a larger share of their wages ended managers following banking deregulation. To assess the role that gender and other employee characteristics may have played in the ECI results, I turn to the CPS data. I first repeat the wage equation estimates of Table 6 using CPS data. The results appear in the first column of Table 8. Using the specification I applied to BLS data, which excludes any controls for worker characteristics, I again find substantial betweenoccupation narrowing among banking industry employees following deregulation. Managers' wages declined by almost 10\% following deregulation, while non--managers experienced no significant 
wage changes. ${ }^{25}$ Interestingly, the point estimates are much smaller using the CPS data. Moving the left or right in Table 8, I progressively add additional controls for worker background characteristics. I find that the results of the first column are substantially robust to including controls for education, age, and race. Controls for gender, however, eliminate the between-occupation narrowing. I conclude that between-occupation narrowing in the ECI data is not driven by trends in banking employee education, age or race. Rather, like Black and Strahan, I find that declining gender differentials in banking following deregulation are behind the observed decline in manager wages relative to non-manager wages. ${ }^{26}$

Black and Strahan present compelling evidence that wage declines among men in the banking industry were driven by erosion of rents that men had disproportionately captured in the form of higher wages. Rather than repeat their analysis, I present additional support for this claim in Table 9. Table 9 shows that banking employment overall, and for men in particular, increased following deregulation. Employment gains were greatest among managers and growth in managerial employment occurred at roughly the same rates for men and women. I find no evidence that occupations in banking became "feminized"; indeed, I find that if anything, banking increased its share of male employees following deregulation. Strong absolute and relative employment growth among male banking employees, combined with evidence that changing characteristics of banking

\footnotetext{
${ }_{25}$ Point estimates were similar but not significant what I restricted the CPS data to the same period covered by the ECI data, 1987-2000.

${ }^{26}$ For the most part, my estimates confirm results published in Black and Strahan (2001). An exception is the fact that I find no difference in the wage declines experienced by male managers and non-managers. This may be due to differences in coding occupations as managerial or non-managerial.
} 
employees had little role in wage declines, confirms that wage declines among men in banking following deregulation were due to the erosion of above-market wages under the regulatory régime. ${ }^{27}$

\section{Between-Establishment Changes}

As was the case with narrowing between-occupation inequality, a number of channels might explain the increases in between-establishment inequality that occurred in the banking industry following deregulation. One possibility is that firm size compensation premiums might have shifted following deregulation. The compensation differential between small firms and large firms might increase if, for example, small firms earned a disproportionate share of pre-deregulation rents. Alternatively, the differential might also increase if large firms begin hiring more able people relative to small firms when faced with a more competitive product market.

I tested for changes in the establishment size-compensation premium among banking employees using regressions of $\log$ compensation similar to those in Table 6 . In addition to the Table 6 covariates, I added dummy variables for eight size classes of establishments and interacted these with the banking and banking*deregulation indicators. The results showed a positive and significant relationship between establishment size and compensation in the ECI data, just as in the firm size literature. ${ }^{28}$ I then allowed the effect of establishment size to differ for banking industry

\footnotetext{
${ }^{27}$ Even with detailed data on individuals like that in the CPS, it is impossible to entirely rule out changing employee quality as an explanation for wage declines following banking deregulation. However, it seems unlikely that male and female employees would diverge in their levels of post-deregulation quality. Also, the analysis finding of withinestablishment relative declines in the ECI data also suggest that quality trends were not a major factor, as existing establishments are unlikely to have shifted rapidly toward lower quality managers following deregulation. ${ }^{28}$ The wage effect of establishment size did not differ between banking employees and employees of other industries.
} 
employees before and after deregulation. I found no evidence that the establishment size premium for banking employees changed following deregulation.

A second channel through which between-establishment inequality might have increased is that the distribution of banking establishments over the range of establishment sizes may have changed following deregulation. Unfortunately, the ECI is a poor data set with which to compare distributions of establishments at different points in time. I again turn to the CPS to shed light on this question. Starting in 1987, the March CPS asks respondents for the size of the firm at which they are employed. ${ }^{29}$ Firm size is reported in seven categories. In Table 10, I show the distribution of banking employees before and after deregulation in two ways. The first two columns give banking's share of total employment within firm size categories. The shares were constructed at the state-year level and averaged within pre-deregulation and post-deregulation groups. The last two columns simply give the share of banking employment represented by each firm size category. Again, shares were computed at the state-year level and averaged across the two groups.

Banking's share of employment in the largest firm size category increased following deregulation, while its share in smaller firm size categories declined. In other words, banking employment at the largest firms grew faster following deregulation than employment at large firms generally, within a given state and year. These trends are consistent with the consolidation through purchases of existing banks that occurred following deregulation. Examination of the share of banking employment by firm size category tells almost the same story. However, in this case I find some evidence of a "hollowing out" in the middle of the post-deregulation distribution. This

\footnotetext{
${ }^{29}$ Firm size and establishment size are not the same. It is likely that the relationship between the two (in banking) changed following deregulation as establishment size fell and firm size increased. Nevertheless, if larger firms pay higher wages across their establishments, changes in firm size may shed some light on changing between-establishment inequality.
} 
suggests that employment growth accounted for by the smallest banking firms did not keep pace with employment growth in that category more generally. Nevertheless, small banking firms accounted for a somewhat larger share of banking employment following deregulation. This is consistent with a proliferation of new entrants as barriers to entry fall. Rank tests at the bottom of the table reject significant distributional shifts across the two periods, but trends in both distributions point to increasing between-firm (and therefore potentially also between-establishment) inequality post-deregulation.

\section{Within-Occupation Changes}

Several authors have discussed implications of deregulation and increased product market competition for within-occupation inequality (Guadalupe, 2003; Hubbard and Palia, 1995; Black and Strahan, 2001), and it has been important in the recent wage structure literature (Katz and Murphy, 1992). The ECI is not ideally suited to studying within-occupation inequality due to its limited detail on occupation, demographic characteristics, and the averaging of wages across groups of employees. Nevertheless, given its importance in recent literature, I look briefly at the effects of banking deregulation on within-occupation inequality for managers and non-managers.

I constructed three measures of within-occupation wage inequality by state, year, two-digit industry, and managerial status cells: the first is variance of log wages; the second the ratio of the 90th percentile log wage to the 10 th percentile; and the third the ratio of the 75 th percentile log wage to the $25 \mathrm{th}^{30}$ I regressed these measures, separately for managers and non-managers, on the

\footnotetext{
${ }^{30}$ Note that these measures of within-occupation inequality incorporate both between-establishment inequality and residual inequality that is not explained by occupation or establishment. These are similar to measures of withinoccupation inequality constructed when establishment identifiers are not available. Also, I focus on wages here since earlier decompositions indicated that using total compensation as opposed to wages did not yield different results.
} 
banking-deregulation interaction, state-year dummies, industry dummies, and interactions of the industry dummies with deregulation. Results are presented in Table 11. I find no evidence that deregulation increased wage variance within either of the two occupation groups I study. I find some evidence that the range of manager wages increases following deregulation, even if variance did not change. Both the 90:10 and the 75:25 wage ratios increased significantly after deregulation among bank managers. The evidence on the spread in non-manager wages suggests that, if anything, their spread narrowed following deregulation, although only the change in the 75:25 ratio is significant. These results are unique to the ECI data. Similar calculations using the CPS did not find any significant changes in within-occupation inequality. Possibly, topcoding in the CPS is responsible for the difference, but this is unclear. ${ }^{31}$

\section{E. Effect of Product Market Competition on Non-Wage Compensation}

One of the ECI's most interesting features is the detailed information on benefits costs that it contains. Although changes in relative levels of benefits do not drive the major changes in the post-deregulation banking compensation structure, interesting changes may nevertheless occur within the benefit structure, particularly if providing incentives for performance becomes more important to firms following deregulation. In addition to hourly wages, the ECI collects information about the average costs of sixteen types of non-wage compensation. Four of these are federally mandated benefits, ${ }^{32}$ and three of these are an extremely small share of the average

\footnotetext{
${ }^{31}$ Note that Pierce (2001) also finds greater increases in inequality in the top half and lesser increases in the bottom half of the wage and compensation distributions using the ECI than those suggested by CPS data. It appears that the ECI captures more high earners at the expense of missing low earners.

32 Social security/Medicare, Worker's Compensation, State Unemployment Insurance, and Federal Unemployment Insurance.
} 
employer's cost. ${ }^{33}$ I focus on the seven benefits categories that are both large and voluntary: vacations and holidays, leave, non-production bonuses, severance packages, health insurance, retirement packages, and overtime pay. ${ }^{34}$ Overtime pay is not strictly non-wage compensation, but in the ECI it is tracked separately from the base wage pay.

Given the nature of their construction, the ECI benefits data are likely better for determining benefits coverage than for making comparisons between job-level benefits expenditures. For this reason, I focus on the impact of deregulation on coverage rates in the seven benefits categories. Inspection of changes in coverage rates for the different benefits categories in banking will explain how overall compensation inequality followed the same patterns as wage inequality post-deregulation. The changing benefits choices of banks following deregulation also provide some evidence about changing firm priorities following deregulation.

For the purposes of computing coverage rates in the ECI data, a job is considered covered by a benefit if an employer's expenditures on the benefit were non-zero for that job. As with the wage data, the ECI's quarterly observations were averaged to form an annual observation; thus, a job is considered covered if expenditures on the benefit were positive for at least one quarter in the year. Table 12 shows broad sample coverage rates for the seven benefits categories of interest. The differences in coverage rates between managers and non-managers in the ECI follows expected patterns. Managers are more likely than non-managers to be covered by health insurance, to have a retirement plan or a severance package, and to receive leave. Managers are less likely to receive

\footnotetext{
${ }^{33}$ Life insurance, Sickness/accident insurance, and Supplemental UI. See Pierce (2001) for a sample of the share of the average employer's contributed by each ECI benefit category.

34 Vacations and holidays are combined into one benefit category in this paper, but they are tracked separately in the ECI. Similarly, the "leave" and "retirement plan" categories in this paper combine the ECI's sick leave and other leave categories and the defined benefits and defined contribution categories, respectively.
} 
overtime pay. Vacations and holidays are offered to the vast majority of workers, although managers receive this benefit at a slightly higher rate. Interestingly, the coverage rate of nonproduction bonuses, hereafter simply bonuses, was no different between managers and nonmanagers.

Table 13 shows the impact of banking deregulation on the coverage rates for the benefit categories of interest. The columns show estimates from regressions of the coverage rate for the shown benefit on the listed controls. For the odd-numbered columns, coverage rates were computed for each of the seven benefit categories for each state-year-industry cell and regressed on a banking industry dummy, a deregulation dummy, their interaction, and state and year fixed effects. In the even numbered columns, coverage rates were computed by state-year-industry-occupation cell, where occupation is a dummy equal to one for managers and zero for non-managers. The even columns include interactions of the banking and deregulation dummies with occupation on the right hand side. The interactions allow me to test whether changes in benefits coverage for the average employee were the same for managers and non-managers.

Estimates on the banking-deregulation interaction in the odd-numbered columns show that the rate of overtime pay and severance packages increased significantly for banking employees following deregulation. The rate of bonus pay declined significantly, and the impact of deregulation on the coverage of other forms of compensation was not significant. Results in the even numbered columns show that these changes generally fell on either managers or non-managers exclusively. The increase in the coverage of overtime pay was entirely accounted for by increasing overtime pay for non-managers. Conversely, the increase in severance packages and the decrease in bonus pay were both entirely accounted for by changes in the coverage rates for these benefits among managers. The one new result in the even numbered columns concerns the leave benefit. Managers became more likely to receive leave following deregulation than they were before while non- 
managers became less likely. These off-setting changes appeared as zero net change in leave coverage for banking employees in column (5). Coverage rates were unchanged for the vacations and holidays, retirement plans, and health insurance benefits data on categories.

The meaning of these changes is difficult to know exactly. Managers' bonuses fall following deregulation, but this does not account for the majority of their relative compensation losses. Apparently, managers were able to channel rents into their wages rather than relying on bonuses. We would expect this from consumption-smoothing agents, but it also suggests that a highly visible bonus might not be the best way for managers to conceal rents from owners. Finally, in contrast to these cost- and workforce-cutting measures, managers were offered severance packages and leave at increasing rates following deregulation. The shift from bonuses to severance packages might indicate a switch from carrot to stick in order to incentivize managers, particularly in a changed environment in which firing of managers is possible. ${ }^{35}$ Some authors have theorized that firms value competence more highly when faced with a more competitive product market (Guadalupe, 2003; Hubbard and Palia, 1995). This change in the managerial benefit structure suggests that the threat of firing is a better tool for achieving this goal than the lure of bonuses. The increase in managerial leave is somewhat mysterious. It may reflect a more competitive labor market for bank managers in which banks try to hire more competent managers away from industries in which leave is more common.

\footnotetext{
35 This is interesting in light of a debate between Hart (1983) and Scharfstein (1988) concerning the effect of increased product market competition on managerial slack. Their opposing results hinged on different assumptions about managers' risk aversion, and in particular, managers' concerns about "the worst state," in which they lost their jobs. Alternatively, this shift may indicate the advent of tough times for firms in which lower profits force them to cut bonuses and undertake layoffs necessitating severance pay.
} 


\section{Conclusion}

Markets for a range of goods and services have become more competitive in recent decades as governments dismantle industry-specific regulations and as increasing numbers of firms compete to sell their goods internationally. These forces have had predictable effects on goods prices and availability, but their effects on labor market outcomes for workers who produce for these markets is less well-known. The effects of product market competition on the distribution of compensation in an industry are particularly poorly understood. This paper examined the effects that liberalization of the product market in one particular U.S. industry, commercial banking, had on various dimensions of the compensation structure for industry employees. The easing of banking industry regulations increased competition between banking firms by lowering geographic barriers to expansion. Banking deregulation also greatly reduced barriers to entry and restrictions on scale. These changes had the potential to alter the banking compensation structure through a number of channels, including the erosion of any non-competitive rents paid out in compensation, a change in firm size distribution in the industry, or shifting incentive problems.

I used data with establishment and occupation identifiers from the U.S. Bureau of Labor Statistics' Employment Compensation Index Survey (ECI) to construct measures of the distribution of compensation by state, year and industry. Variation in the timing of banking deregulation across U.S. states then provided identification of deregulation's effects on these measures at the state-yearindustry level. I supplemented this analysis with estimates using data from the March CPS, which has more detailed data on worker characteristics than the ECI but little information about a worker's employment establishment.

Deregulation had no impact on overall compensation inequality in the banking industry. However, this concealed a number of significant changes within the banking compensation structure. Manager wages fell while non-manager wages held steady, leading to a large decline in 
between-occupation compensation inequality. In contrast, between-establishment inequality increased dramatically. These changes in inequality were accomplished almost entirely through wage changes. I also find evidence that deregulation led to increased inequality within the group of managerial employees, despite their falling wages. Finally, deregulation led to significant shifts in the types of non-wage benefits banking employees received within the main occupation groups of managers and non-managers.

Using CPS data, I am able to add some detail to the broad changes identified in the ECI findings. The decline in between-occupation inequality was achieved through large reductions in manager wages following deregulation while non-manager wages remained constant. Like Black and Strahan (2001), I find that this is due to differential effects on men and women in the banking industry. I find that the increase in between-establishment inequality is related the changing firm size distribution within the banking industry following deregulation. CPS data shows that banking employees increased their representation in the largest firm size category following deregulation at the expense of representation in all smaller categories. Among banking employees, the share in the largest and smallest firm size categories increased following deregulation. Such shifts would increase between establishment inequality, given what is known about the firm size wage premium.

In cases where my analysis coincides with theirs, the findings in this paper generally support those of other authors who have studied banking industry compensation following deregulation. What appear at first to be differences between my findings and those in Black and Strahan (2001) can in fact be explained by differences in available covariates across our datasets. The comparison highlights the fact that two important, nationally representative data sets can nevertheless produce different empirical results. My finding of increasing inequality among managers despite falling average wages is consistent with Hubbard and Palia (1995), who show that bank CEOs in more competitive markets earn more. [Add stuff from Card/Rose/Winston/Guadalupe? I find no 
evidence that deregulation increased wage dispersion within the group of non-managerial bank employees. The effects of deregulation on the banking compensation structure differ in important ways from the effects of liberalization that have been observed in other industries. The banking example suggests that liberalization of a heavily unionized, capital-intensive industry with large economies of scale plays out very differently from liberalization of a non-unionized, labor-intensive industry with modest economies of scale.]

For those concerned about the effects of deregulation on inequality among workers, the example of the banking industry provides mixed conclusions. The evidence contradicts popular assumptions that competition and liberalization inevitably increase wage inequality and harm lowskilled workers. For example, the cost-cutting pressures of increased product market competition likely eroded rents that were the source of managerial wage premiums in the banking industry, accruing in particular to men. On the other hand, regulatory restrictions on entry and scale had created an industry in which banking firms were of relatively similar sizes and thus paid similar wages, leading to more homogeneity in compensation for banking employees in the regulatory era than would be the case following deregulation. Deregulation also led to changes in non-wage compensation that suggest a change in the work environment with welfare consequences for workers that are difficult to quantify. As this example makes clear, no single measure of inequality will capture all relevant compensation structure changes that accompany liberalization. Taken together, these results underscore the importance of evaluating several dimensions of the compensation structure before conclusions about the impacts of a regulatory change on workers are drawn. 


\section{References}

Berger, Allen N., Anil K Kashyap, and Joseph M. Scalise, "The Transformation of the U.S. Banking Industry: What a Long, Strange Trip It's Been," Brookings Papers on Economic Activity, 1995 (1995), 55201.

Berger, Allen N., Nathan H. Miller, Mitchell A. Petersen, Raghuram G. Rajan, and Jeremy C. Stein. "Does Function Follow Organizational Form? Evidence from the Lending Practices of Small and Large Banks." Journal of Financial Economics 76 (2005), 237-269.

Bergstresser, Daniel, "Market Concentration and Loan Portfolios in Commercial Banking,” Ph.D. Dissertation, MIT University, 2001.

Black, Sanrda E. and Elizabeth Brainerd, "Importing Inequality? The Impact of Globalization on Gender Discrimination,” Industrial and Labor Relations Review (July 2004).

Black, Sandra E., and Philip E. Strahan, "The Division of Spoils: Rent-Sharing and Discrimination in a Regulated Industry," Quarterly Journal of Economics, 91 (Sept. 2001), 814-831.

Brown, Charles and Medoff, James, "The Employer Size Wage Effect.” Journal of Political Economy, (October 1989).

Card, David, "Deregulation and Labor Earnings in the Airline Industry," NBER Working Paper \#5687, (July 1996). 
Cannon, Sandra A., Bruce C. Fallick, Michael Lettau, and Raven Saks, "Has Compensation Become More Flexible," Board of Governors of the Federal Reserve System Working Paper (April 2000).

Economides, Nicholas, R. Glenn Hubbard, and Darius Palia, “The Political Economy of Branching Restrictions and Deposit Insurance: A Model of Monopolistic Competition Among Small and Large Banks,” NBER Working Paper No. 5210, (August 1995).

Flannery, Mark J., “The Social Costs of Unit Banking Restrictions,” Journal of Monetary Economics, 13 (1984), 237-249.

Fortin, Nicole M. and Thomas Lemieux, "Institutional Changes and Rising Wage Inequality: Is There a Linkage?” Journal of Economic Perspectives, 11 (Spring 1997), 75-96.

Groshen, Erica L., "Sources of Intra-Industry Wage Dispersion: How Much Do Employers Matter?” Quarterly Journal of Economics, (Aug. 1991), 869-884.

Guadalupe, Maria, “Does Product Market Competition Increase Wage Inequality?” Manuscript. London: London School of Economics (2003).

Hart, Oliver D., "The Market Mechanism as Incentive Scheme,” The Bell Journal of Economics, 14 (1983), 366-382. 
Hubbard, R. Glenn, and Darius Palia, "Executive Pay and Performance: Evidence from the U.S. Banking Industry," Journal of Financial Economics, 39 (1995), 105-130.

Jayaratne, Jith, and Philip E. Strahan, “The Finance-Growth Nexus: Evidence from Bank Branch Deregulation," Quarterly Journal of Economics, 111 (1996).

$\ldots$, and __ "Entry Restrictions, Industry Evolution, and Dynamic Efficiency: Evidence from Commercial Banking," Journal of Law and Economics, (1998).

Kane, Edward J., "De Jure Interstate Banking: Why Only Now?” Journal of Money, Credit, and Banking, 28 (May 1996), 141-161.

Katz, Lawrence F. and Kevin M. Murphy, “Changes in Relative Wages, 1963-1987: Supply and Demand Factors," Quarterly Journal of Economics, 107 (Feb. 1992), 35-78.

Kremer, Michael and Eric Maskin. "Wage Inequality and Segregation by Skill,” NBER Working Paper \#5718 (August 1996).

Kroszner, Randall S., and Philip E. Strahan, "What Drives Deregulation? Economics and Politics of the Relaxation of Bank Branching Restrictions," Quarterly Journal of Economics, (Nov. 1999), 1437 1467. 
Nakamura, Leonard I., "Commercial Bank Information: Implications for the Structure of Banking," in Structural Change in Banking, Klausner, Michael, and Lawrence J. White, eds. (Homewood, IL: Business One Irwin, 1993).

OECD, "And the Twain Shall Meet: Cross-Market Effects of Labour and Product Market Policies," OECD Employment Outlook, (May 2002).

Peoples, James. "Deregulation and the Labor Market," Journal of Economic Perspectives, 12 (Summer 1998), 111-130.

Pierce, Brooks, “Compensation Inequality," Quarterly Journal of Economics 116 (Nov. 2001) 1493-1525.

Rhoades, Stephen A., "Bank Mergers and Banking Structure in the United States, 1980-1989," Board of Governors of the Federal Reserve System Staff Study 174, (Aug. 2000).

Rose, Nancy L., "Labor Rent Sharing: Evidence from the Trucking Industry," Jounal of Political Economy, 95 (Dec. 1987), 1146-1178.

Rose, Peter S., The Changing Structure of American Banking (New York, NY: Columbia University Press, 1987).

Scharfstein, David, "Product Market Competition and Managerial Slack," RAND Journal of Economics, 19 (Spring 1988), 147-155. 
Sylla, Richard, and John B. Legler, and John J. Wallace, "Bank and State Public Finance in the New Republic: The United States, 1790-1860," Journal of Economic History, XLVII (June 1987), 391-403.

U.S. Department of Labor Bureau of Labor Statistics, BLS Handbook of Methods (U.S. Government Printing Office Bulletin 2490, 1997).

Watt, James B., “Actions by States Will Shape Transition to Interstate Branching," Banking Policy Report, 13 (Aug. 1994), 27-34.

White, Eugene, The Regulation and Reform of the American Banking System, 1900-1929 (Princeton, NJ:

Princeton University Press, 1983)

Winston, Clifford, “Economic Deregulation: Days of Reckoning for Microeconomists," Journal of Economic Literature, 31 (September 1993), 1263-1289. 


\section{Data Appendix}

The primary data source used in this paper is the U.S. Bureau of Labor Statistics Employment Cost Index (ECI) microdata. BLS collects the ECI data in order to construct the quarterly index of the same name, which is used to track wage and benefits levels, coverage, and costs (to employers) across industries and geographic areas. The BLS collects the ECI data from establishments, defined by the BLS as consisting of all employees of a firm at a given physical address. Approximately every five years, an establishment sample is drawn randomly from within strata defined by establishment size, industry and location. Establishments in government or agriculture are excluded. In keeping with its purpose as an index of employer costs, the ECI data contains no individual worker-level or demographic information. Instead, the observational unit in the ECI is the "job." One should think of a job as an occupation--union status--full-time status cell. $^{36}$ The establishment provides data averaged over all employees in sampled jobs. Data for between two and eight jobs are collected from each establishment, depending on the establishment's size. Given their size, banking establishments typically provide data on four to six jobs.

The resulting data set is a rotating panel as jobs are not resampled over an establishment's time in the survey (U.S. Department of Labor, 1997). Each job observation includes the job's average wage within the establishment, constructed from quarterly hours and earnings; the average expenditures on fifteen different benefit categories for employees in the job; a one-digit occupational code; a four digit industry code; full-time or part-time status; union status; state; the establishment identifier; number of employees in the establishment; and in some cases, a county

\footnotetext{
${ }^{36}$ For example, two bank tellers in the same establishment would be considered to be in the same job if both were also full-time employees and not union members. The two would be considered to be in different jobs if one was employed part-time and the other full-time. In the first case, their information would be averaged together to form the job observation. In the second, their information would go into different job averages.
} 
FIPS code identifying the establishment's location. The ECI data begin in 1979, but the sample in this paper is restricted to the years 1987-2001. The earlier data are discarded because the ECI did not constitute a reliably representative sample of industries or jobs in those years.

The ECI benefits data are collected using the same methods as the wage data. Each establishment is asked to provide the total amount spent on each benefit type in the previous quarter, aggregating over all employees in a job. This aggregate amount is then divided by the total hours worked by all employees in that job during the previous quarter to arrive at the employer's average per hour expenditure on employees in the job for each benefit type. Due to the nature of some expenditures, like health insurance, job-specific figures within an establishment may be difficult to compute with accuracy. Nevertheless, I construct a total hourly compensation figure at the job level by summing the wage expenditures and benefits expenditures reported for each job. The specific benefits categories will be discussed in more detail in Section VI. ${ }^{37}$

The ECI data begin in 1979, but the sample in this paper is restricted to the years 1987-2001. The earlier data are discarded because the ECI did not constitute a reliably representative sample of industries or jobs in those years. Rather, some emphasis was placed on collecting data from industries and on jobs in which the government had a greater interest, and banking in particular is a disproportionately small share of the ECI in the 1979-1986 period. Job observations with zero hours recorded and with hourly wage rates in the top or bottom 0.5 percent of the distribution in each year were also discarded..$^{38}$ The remaining sample consists of approximately 330,000 job observations over a 15 -year period. About 10,000 of these are in banking. The ECI constructs weights to produce representative estimates from its stratified random sample. Unfortunately, no effort is made to replace establishments that drop out of the sample prior to the 5-year

\footnotetext{
${ }^{37}$ See Pierce (2001) for a discussion of how employer benefits costs relate to employee evaluation of benefits.

38 This follows established procedures for working with the ECI. See Cannon et al. (2000).
} 
replenishment, and the weights are only recalculated at the time of replenishment. To correct for the fact that recently sampled industries will constitute a disproportionate share of the ECI (relative to older industry samples), the ECI weights were rescaled to total to industry employment in each year as published in the County Business Patterns Data. ${ }^{39}$

39 Thanks to Brooks Pierce for providing this data and coding for the adjustment. 


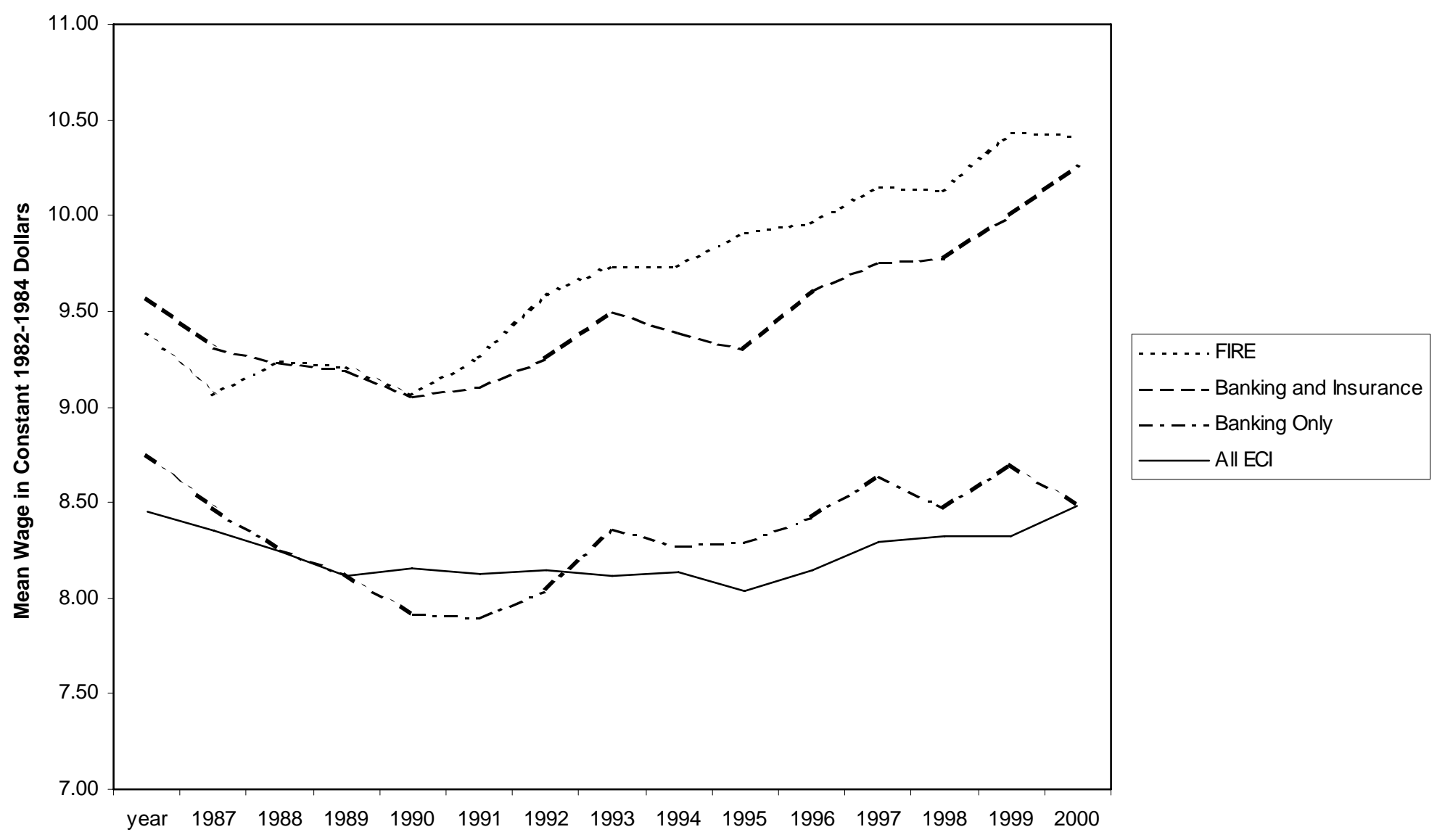

Figure 1: Mean Wages in the ECI 
Table 1: Years of Deregulation: States and the Years They Permitted M\&A Branching

Early Deregulators: M\&A Branching Permitted Prior to 1970 (12 states)

Alaska

Arizona

California

DC

Delaware no years available

Idaho for this group

Maryland

Nevada

North Carolina

Rhode Island

South Carolina

South Dakota

M\&A Branching Permitted Starting 1970-1979 (6 states)

Vermont $\quad 1970$

Maine 1975

New York 1976

New Jersey $\quad 1977$

Virginia 1978

Ohio 1979

M\&A Branching Permitted Starting 1980-1986 (12 states)

Connecticut $\quad 1980$

Alabama 1981

Utah 1981

Pennsylvania 1982

Georgia 1983

Massachusetts $\quad 1984$

Nebraska $\quad 1985$

Oregon 1985

Tennessee 1985

Washington 1985

Hawaii 1986

Mississippi 1986

M\&A Branching Permitted Starting in 1987 (5 states)

Kansas 1987

Michigan 1987

New Hampshire $\quad 1987$

North Dakota $\quad 1987$

West Virginia 1987

Treatment States: M\&A Branching Permitted Starting 1988 or Later (16 states)

Florida

Oklahoma 1988

Texas 1988

Wyoming 1988

Indiana 1989

Kentucky 1990

Missouri 1990

Montana 1990

Wisconsin $\quad 1990$

Colorado 1991

New Mexico 1991

Minnesota 1993

Arkansas 1994

lowa [1994]

Data based on Black and Strahan (2001), Amel (1993), and Kroszner and Strahan (1999). lowa had not yet deregulated in 1994, the year in which IBBEA passed allowing interstate branching and superseding state branching laws. For the analysis, lowa is considered to have deregulated in 1994, but results are not sensitive to this.

Treatment states are those in which the deregulatory change is observed in the BLS data. 


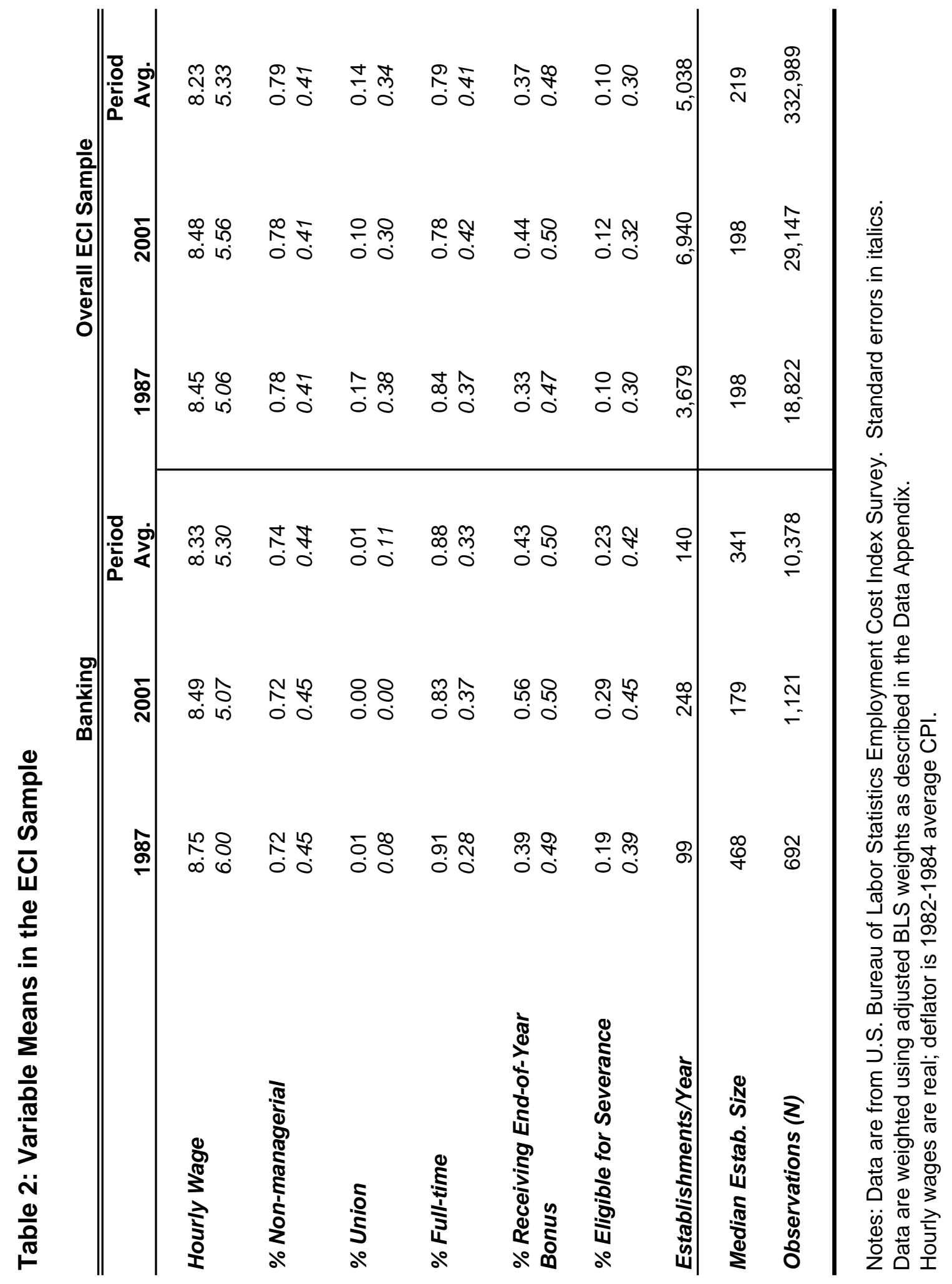


Table 3: Means of Constructed Variance Components

\begin{tabular}{|c|c|c|}
\hline & $\begin{array}{c}\text { Decomposition of } \\
\text { Wages }\end{array}$ & $\begin{array}{l}\text { Decomposition } \\
\text { Total Compensa }\end{array}$ \\
\hline \multicolumn{3}{|l|}{ Lower Bound Measures } \\
\hline Total Variance & $\begin{array}{l}0.155 \\
0.002\end{array}$ & $\begin{array}{l}0.145 \\
0.002\end{array}$ \\
\hline Between-Occupation & $\begin{array}{l}0.044 \\
0.001\end{array}$ & $\begin{array}{l}0.037 \\
0.001\end{array}$ \\
\hline Between-Establishment & $\begin{array}{l}0.035 \\
0.001\end{array}$ & $\begin{array}{l}0.039 \\
0.001\end{array}$ \\
\hline Between-Estab. \& Occ. Cell & $\begin{array}{l}-0.017 \\
0.001\end{array}$ & $\begin{array}{l}-0.014 \\
0.001\end{array}$ \\
\hline Residual & $\begin{array}{l}0.079 \\
0.001\end{array}$ & $\begin{array}{l}0.076 \\
0.001\end{array}$ \\
\hline \multicolumn{3}{|l|}{ Upper Bound Measures } \\
\hline Total Variance & $\begin{array}{l}0.155 \\
0.002\end{array}$ & $\begin{array}{l}0.145 \\
0.002\end{array}$ \\
\hline Between-Occupation & $\begin{array}{l}0.059 \\
0.001\end{array}$ & $\begin{array}{l}0.051 \\
0.001\end{array}$ \\
\hline Residual, Occupation Reg. & $\begin{array}{l}0.097 \\
0.001\end{array}$ & $\begin{array}{l}0.093 \\
0.001\end{array}$ \\
\hline Between-Establishment & $\begin{array}{l}0.049 \\
0.001\end{array}$ & $\begin{array}{l}0.052 \\
0.001\end{array}$ \\
\hline Residual, Establishment Reg. & $\begin{array}{l}0.106 \\
0.001\end{array}$ & $\begin{array}{l}0.101 \\
0.001\end{array}$ \\
\hline
\end{tabular}

Notes: Data are from U.S. Bureau of Labor Statistics Employment Cost Index Survey, 1987-2001. Table shows means and standard errors (in italics) of variance components constructed as described in text. Wage decomposition measures have $\mathrm{N}=6522$. Compensation decomposition measures have $\mathrm{N}=6420$. 


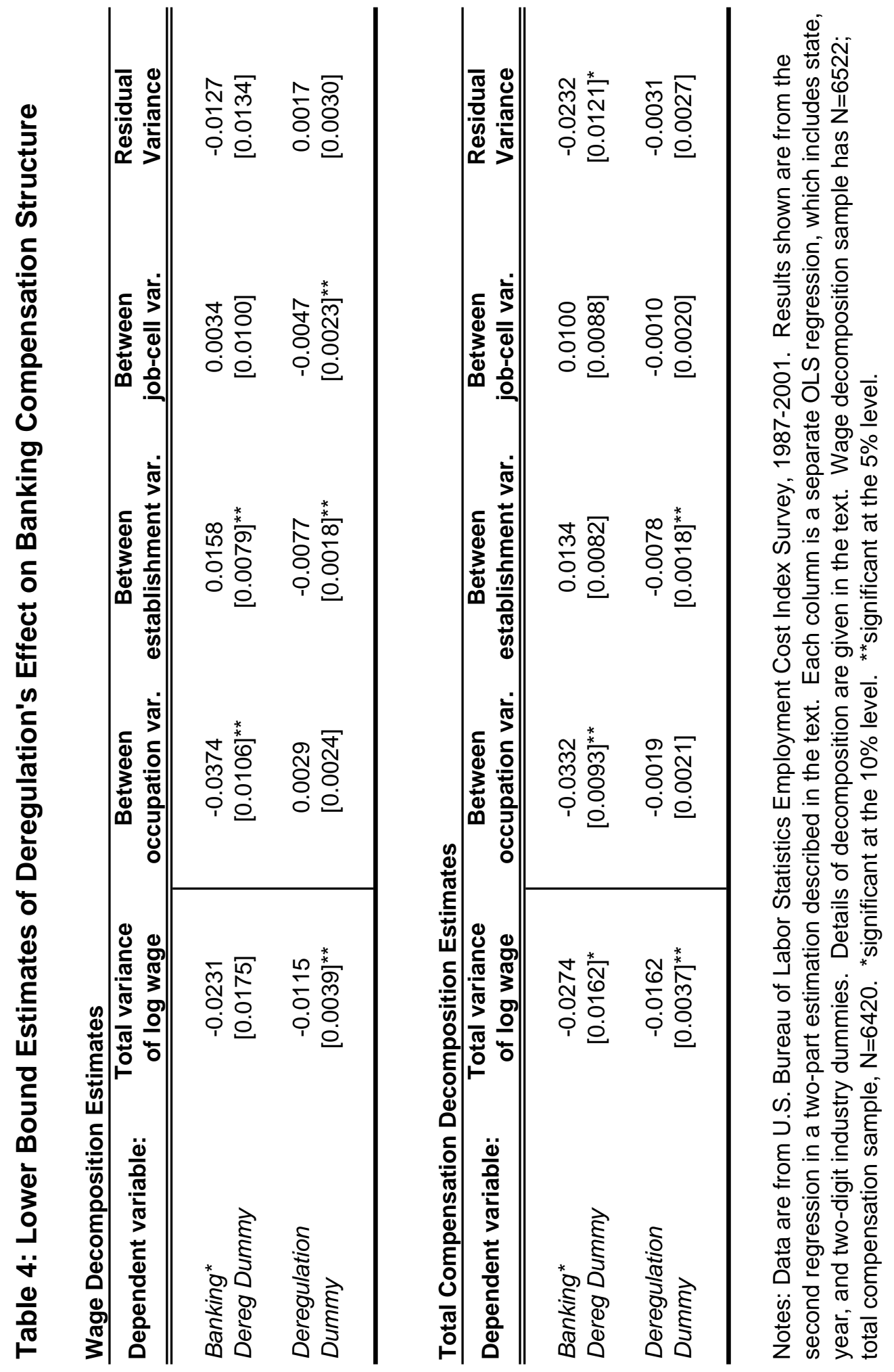




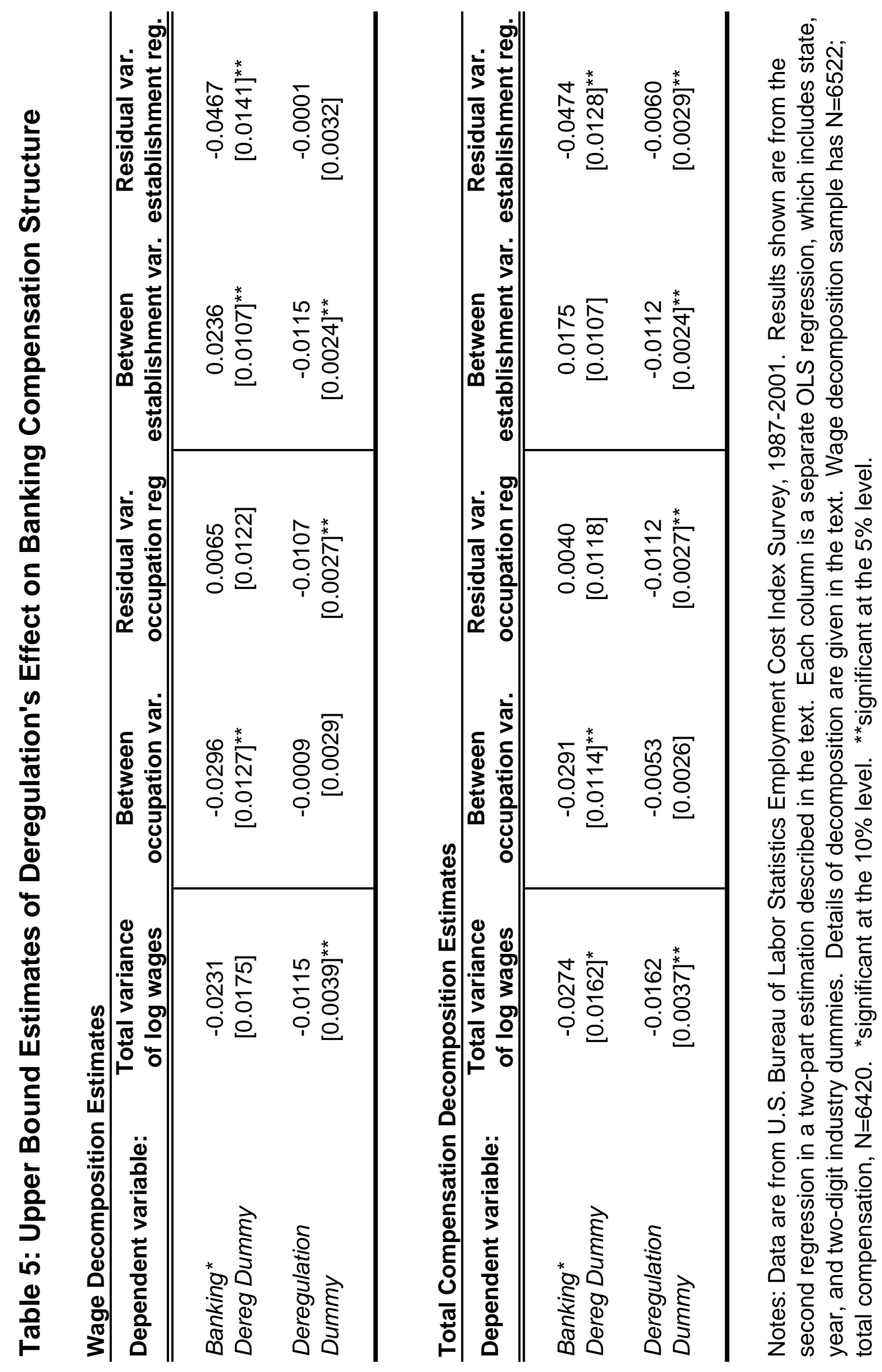


Table 6: Effect of Banking Deregulation on Compensation by Occupation and Industry

\section{Dependent Variable:}

Log Wages

Log Total Compensation

\begin{tabular}{|c|c|c|c|c|c|c|}
\hline & [1] & [2] & [3] & [4] & [5] & [6] \\
\hline $\begin{array}{l}\text { Banking*Dereg } \\
\text { Interaction }\end{array}$ & $\begin{array}{c}0.015 \\
{[0.039]}\end{array}$ & $\begin{array}{c}-0.167 \\
{[0.064]^{\star *}}\end{array}$ & $\begin{array}{c}-0.182 \\
{[0.064]^{\star *}}\end{array}$ & $\begin{array}{l}-0.007 \\
{[0.047]}\end{array}$ & $\begin{array}{c}-0.203 \\
{[0.073]^{\star *}}\end{array}$ & $\begin{array}{c}-0.222 \\
{[0.073]^{\star *}}\end{array}$ \\
\hline $\begin{array}{l}\text { Banking*Dereg } \\
{ }^{*} \text { Non-manager }\end{array}$ & & $\begin{array}{c}0.246 \\
{[0.061]^{\star *}}\end{array}$ & $\begin{array}{c}0.261 \\
{[0.061]^{\star *}}\end{array}$ & & $\begin{array}{c}0.261 \\
{[0.069]^{\star *}}\end{array}$ & $\begin{array}{c}0.281 \\
{[0.068]^{\star *}}\end{array}$ \\
\hline $\begin{array}{l}\text { Banking } \\
{ }^{*} \text { Non-manager }\end{array}$ & & $\begin{array}{c}0.108 \\
{[0.188]}\end{array}$ & $\begin{array}{c}0.123 \\
{[0.189]}\end{array}$ & & $\begin{array}{c}0.154 \\
{[0.207]}\end{array}$ & $\begin{array}{c}0.165 \\
{[0.209]}\end{array}$ \\
\hline $\begin{array}{l}\text { Dereg } \\
{ }^{*} \text { Non-manager }\end{array}$ & & $\begin{array}{c}-0.068 \\
{[0.029]^{\star \star}}\end{array}$ & $\begin{array}{c}-0.079 \\
{[0.026]^{\star \star}}\end{array}$ & & $\begin{array}{c}-0.058 \\
{[0.030]^{*}}\end{array}$ & $\begin{array}{c}-0.071 \\
{[0.026]^{\star *}}\end{array}$ \\
\hline $\begin{array}{l}\text { Non-manager } \\
\text { Dummy }\end{array}$ & $\begin{array}{c}-0.683 \\
{[0.20]^{\star *}}\end{array}$ & $\begin{array}{c}-0.849 \\
{[0.034]^{* *}}\end{array}$ & $\begin{array}{c}-0.607 \\
{[0.023]^{\star *}}\end{array}$ & $\begin{array}{c}-0.067 \\
{[0.021]^{\star *}}\end{array}$ & $\begin{array}{c}-0.865 \\
{[0.034]^{\star *}}\end{array}$ & $\begin{array}{c}-0.604 \\
{[0.022]^{\star *}}\end{array}$ \\
\hline $\begin{array}{l}\text { Banking Industry } \\
\text { Dummy }\end{array}$ & $\begin{array}{c}0.139 \\
{[0.091]}\end{array}$ & $\begin{array}{c}0.574 \\
{[0.083]^{\star *}}\end{array}$ & $\begin{array}{c}0.548 \\
{[0.084]^{\star *}}\end{array}$ & $\begin{array}{c}0.148 \\
{[0.095]}\end{array}$ & $\begin{array}{c}0.649 \\
{[0.091]^{\star *}}\end{array}$ & $\begin{array}{c}0.623 \\
{[0.093]^{\star *}}\end{array}$ \\
\hline $\begin{array}{l}\text { Deregulation } \\
\text { Dummy }\end{array}$ & $\mathrm{N} / \mathrm{A}$ & $\mathrm{N} / \mathrm{A}$ & $\mathrm{N} / \mathrm{A}$ & $\mathrm{N} / \mathrm{A}$ & $\mathrm{N} / \mathrm{A}$ & $\mathrm{N} / \mathrm{A}$ \\
\hline Union Dummy & $\begin{array}{c}0.281 \\
{[0.027]^{\star \star}}\end{array}$ & $\begin{array}{c}0.002 \\
{[0.032]}\end{array}$ & $\begin{array}{c}0.281 \\
{[0.027]^{\star *}}\end{array}$ & $\begin{array}{c}0.358 \\
{[0.033]^{\star *}}\end{array}$ & $\begin{array}{c}0.018 \\
{[0.029]}\end{array}$ & $\begin{array}{c}0.358 \\
{[0.033]^{\star *}}\end{array}$ \\
\hline Full-time Dummy & $\begin{array}{c}0.418 \\
{[0.011]^{\star *}}\end{array}$ & $\begin{array}{c}0.199 \\
{[0.028]^{\star \star}}\end{array}$ & $\begin{array}{c}0.418 \\
{[0.011]^{\star \star}}\end{array}$ & $\begin{array}{c}0.539 \\
{[0.012]^{\star \star}}\end{array}$ & $\begin{array}{c}0.303 \\
{[0.027]^{\star *}}\end{array}$ & $\begin{array}{c}0.539 \\
{[0.012]^{\star *}}\end{array}$ \\
\hline Non-managerial*Union & & $\begin{array}{c}0.296 \\
{[0.036]^{\star \star}}\end{array}$ & - & & $\begin{array}{c}0.361 \\
{[0.043]^{\star *}}\end{array}$ & - \\
\hline $\begin{array}{l}\text { Non-managerial* } \\
\text { Full-time }\end{array}$ & & $\begin{array}{c}0.255 \\
{[0.029]^{\star *}}\end{array}$ & - & & $\begin{array}{c}0.274 \\
{[0.030]^{* *}}\end{array}$ & - \\
\hline \multicolumn{7}{|c|}{ H0: Banking ${ }^{\star}$ Dereg + Banking ${ }^{\star}$ Dereg ${ }^{\star}$ Non-manager $=0$} \\
\hline $\begin{array}{l}\text { F statistic } \\
p \text {-value }\end{array}$ & & $\begin{array}{c}3.91 \\
0.053\end{array}$ & $\begin{array}{l}4.08 \\
0.049\end{array}$ & & $\begin{array}{c}1.45 \\
0.233\end{array}$ & $\begin{array}{l}1.60 \\
0.212\end{array}$ \\
\hline
\end{tabular}

Notes: Data are from U.S. Bureau of Labor Statistics Employer Cost Index surveys, 1987-2001. In addition to the covariates shown, regressions included a full set of state-year fixed effects, banking-specific year effects, banking-specific state effects, and interactions of banking with occupation, full-time and employer size. Robust standard errors, clustered at the state level, are in brackets. Sample has $\mathrm{N}=331,818$. ${ }^{\star *}$ significant at the $5 \%$ level. ${ }^{*}$ significant at the $10 \%$ level. 


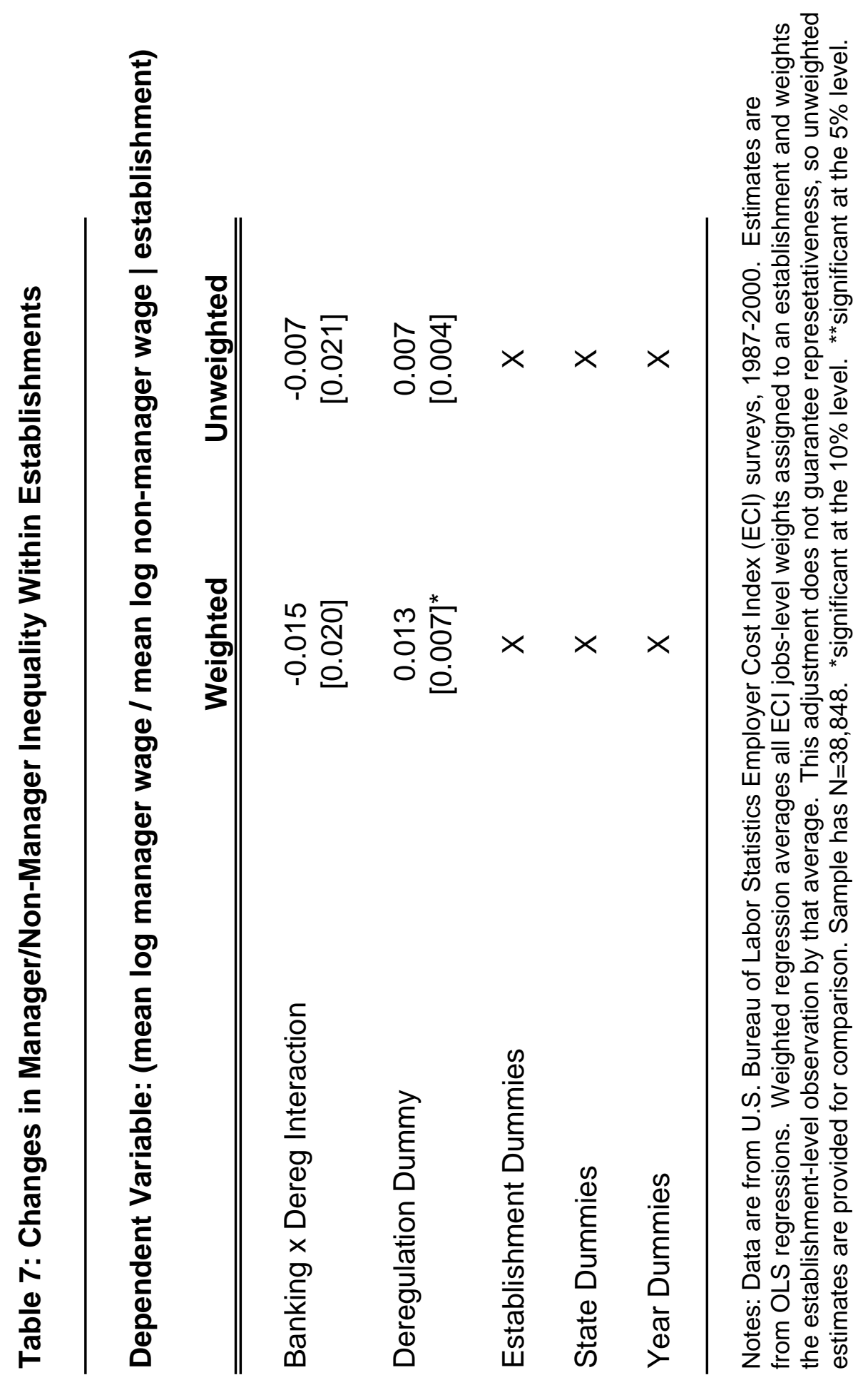




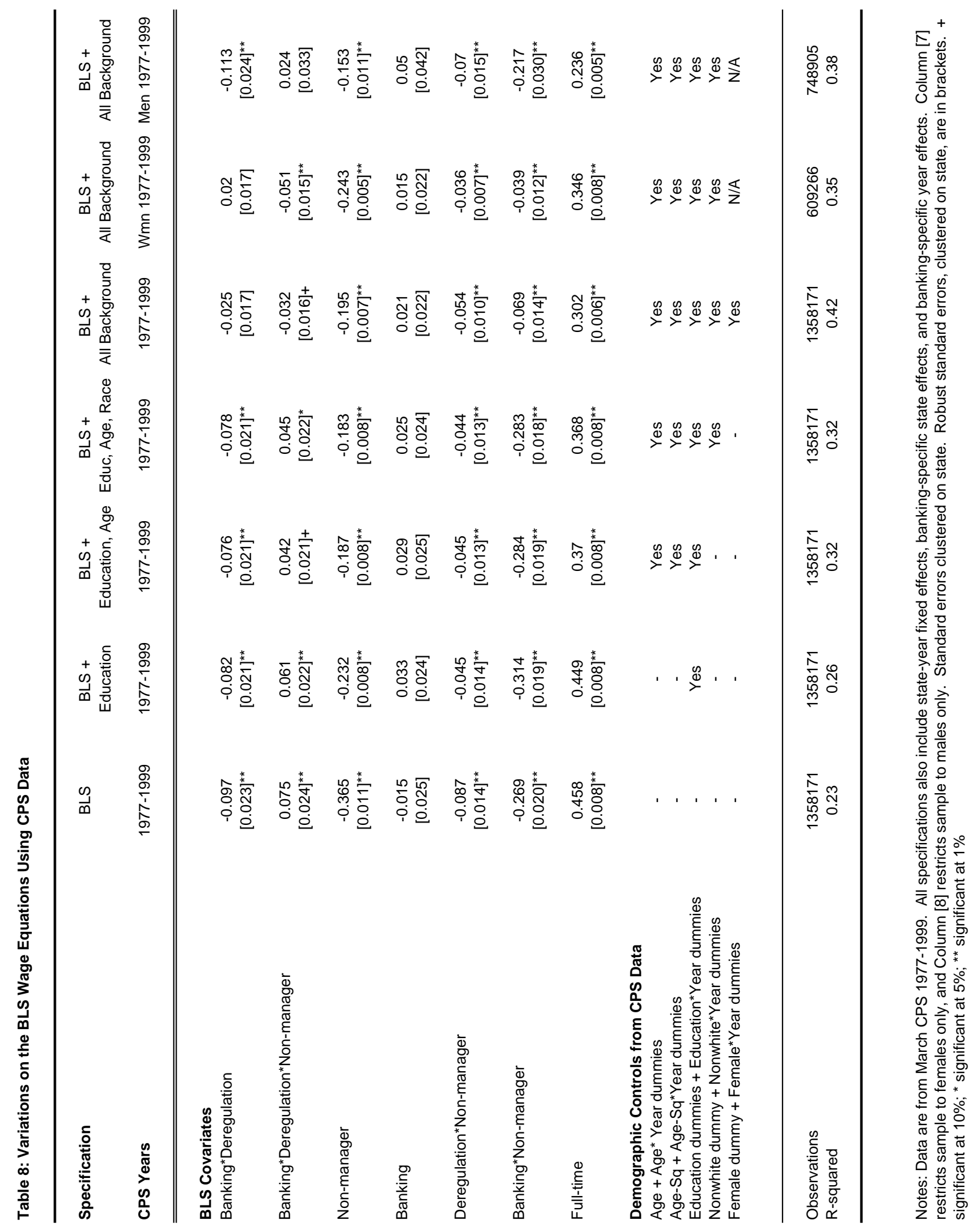




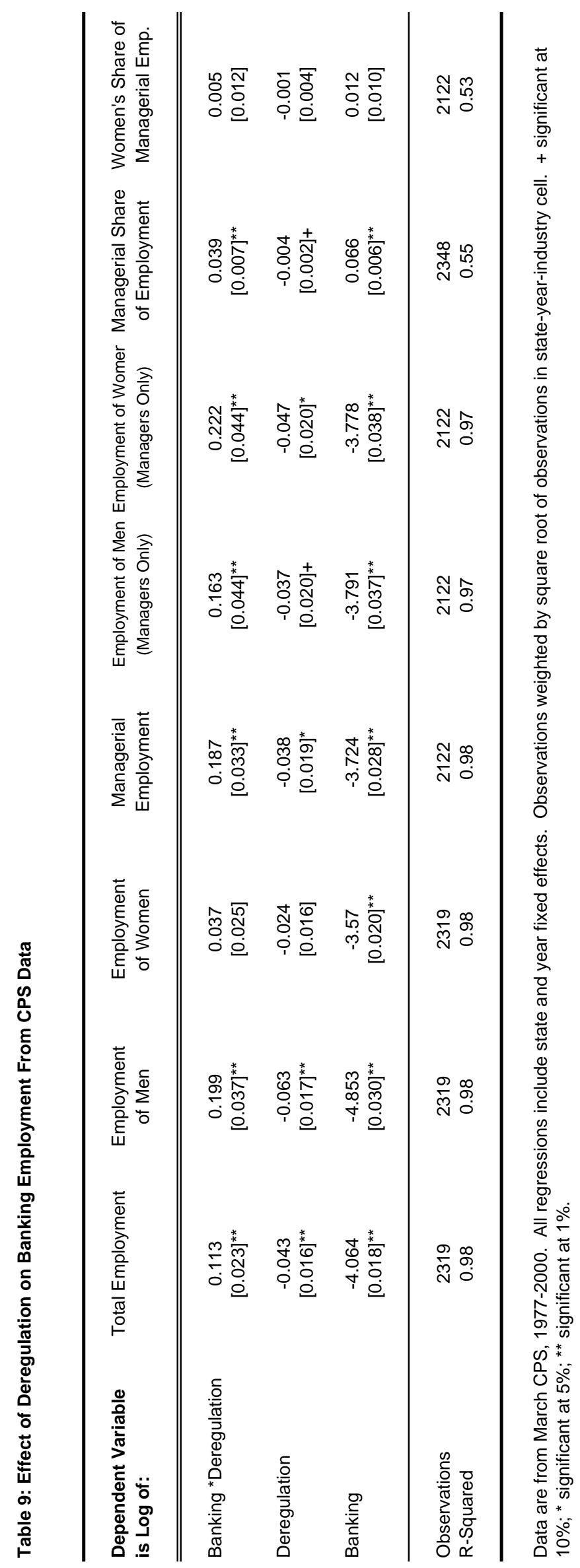


Table 10: Distribution of Banking Employment Over Firm Size Categories in the CPS

\begin{tabular}{lcccc}
\hline & $\begin{array}{c}\text { Banking's Share of Employment } \\
\text { in Firm Size Category }\end{array}$ & $\begin{array}{c}\text { Share of Banking Employment } \\
\text { in Firm Size Category }\end{array}$ \\
& Pre-deregulation & Post-deregulation & Pre-deregulation & Post-deregulation \\
\hline \hline & 0.0098 & 0.0034 & 0.0871 & 0.0653 \\
Under 10 & 0.0389 & 0.0099 & 0.1689 & 0.0893 \\
10 to 24 & 0.0118 & 0.0070 & 0.2002 & 0.0943 \\
Under 25 & 0.0339 & 0.0175 & 0.2819 & 0.1519 \\
25 to 99 & 0.0214 & 0.0203 & 0.2075 & 0.1849 \\
100 to 499 & 0.0328 & 0.0245 & 0.1356 & 0.1076 \\
500 to 999 & 0.0140 & 0.0256 & 0.3267 & 0.5531 \\
$1000+$ & & & & 0.2367 \\
\hline P-value of Rank Test & & 0.1282 & & \\
\hline
\end{tabular}

Notes: Data are from March CPS, 1977-1999. 


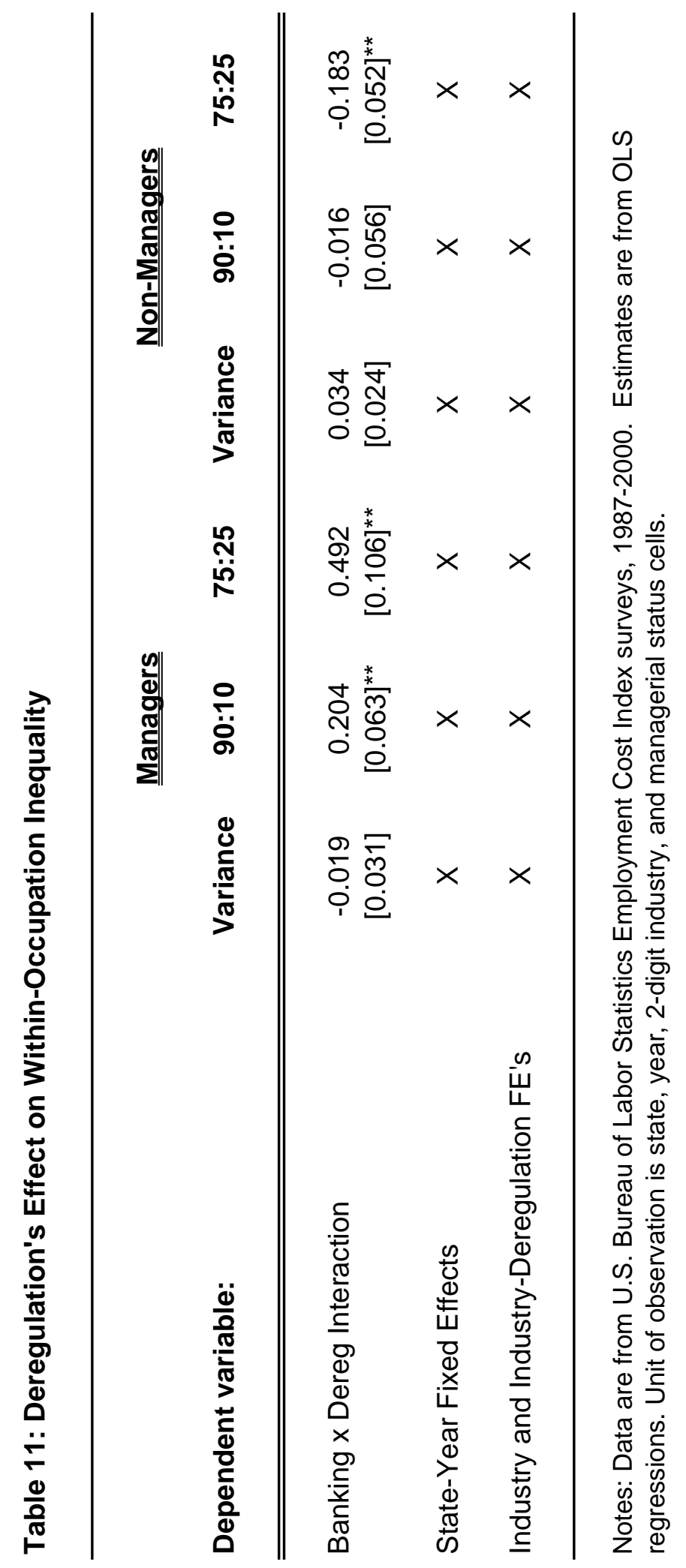


Table 12: Sample Means of Benefit Coverage Variables

\begin{tabular}{lccc}
\hline & Whole Sample & Non-managers & Managers \\
\hline \hline Overtime & 0.53 & 0.59 & 0.29 \\
Vacations and Holidays & 0.84 & 0.83 & 0.91 \\
Leave & 0.66 & 0.61 & 0.82 \\
Non-production Bonus & 0.36 & 0.36 & 0.37 \\
Severance Package & 0.10 & 0.08 & 0.17 \\
Health Insurance & 0.72 & 0.69 & 0.86 \\
Retirement Plan & 0.56 & 0.53 & 0.69 \\
\hline
\end{tabular}

Notes: Data are from U.S. Bureau of Labor Statistics Employment Cost Index Survey, 1987-2001. Standard errors not presented. All standard errors $<0.01$. 


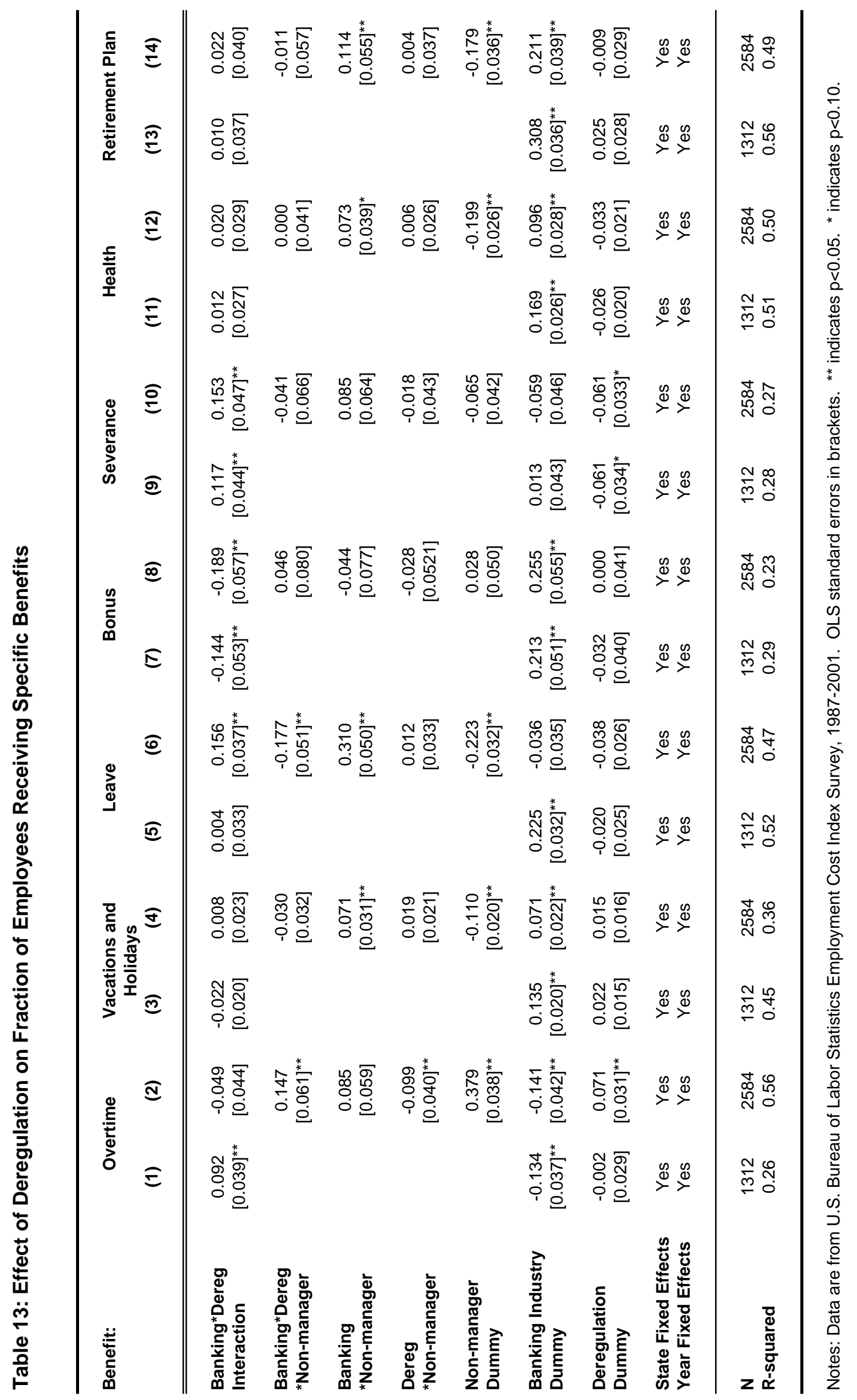

